\title{
AIR RAID DAMAGE
}

\section{University of London}

UnIVERsity College. Some details have already been published in the Press regarding the very serious damage done to the College buildings. The main damage is to the original building and, in particular, to the Library, in which about a 100,000 books have been destroyed. All Faculties of the College remain evacuated.

KING's ColLege. A high explosive bomb fell in the quadrangle, but the damage was less severe than might have been expected. The College had already been evacuated.

WESTFIELd ColLeGe. Incendiary bombs have done damage which is, however, not serious ; the College remains evacuated.

Brrkbeck College. Very serious damage has been done by fire resulting from incendiary bombs. Three laboratories were completely gutted and a fourth severely damaged and a considerable portion of the roof of the theatre destroyed. The main building suffered also from water. The College, however, continues to function.

School of Oriental Studies. Some damage, not considerable, was done to the new building from a high explosive bomb.

Goldsmiths' College. The buildings have been damaged twice and partly wrecked.

Medical Schools : St. Bartholomew's : severe damage has been done to that part of the College which adjoins the hospital. Later, the roof of the College Hall in Charterhouse Square was destroyed by incendiary bombs, and considerable damago was caused by water. St. Thomas's : very severe damage has been done, but work is continuing. Guy's : headquarters and also school properties at Tunbridge Wells have been damaged. London: damage has been done to the Dissecting Room, the Bacteriological Department and Students' Hostel. London School of Medicine for Women: damage has been done by incendiary bombs, particularly to the Anatomy Department; other departments damaged by water. Students' Hostel severely damaged by blast.

\section{Royal College of Surgeons}

BuAst has broken all the-windows and window frames on the north front of the Royal College of Surgeons, torn off doors inside the building and shattered many of the roof lights in the Museums. No structural damage was done except to two partition walls on the fourth floor, which houses the work rooms for the Museum. In the Library Reading Room, little damage was caused. Books and periodicals were found in the College forecourt and on the roadway outside. Broken glass and soot covered the periodical tables and lay thickly all over the floor. Careful cleaning of the books and periodicals was started by the staff and, within a day, the reading room, although windowless, was in use again. Ceiling and shelves damaged by the blast were repaired rapidly and the window openings boarded up. The Museum damage was relatively slight. In Room I, some of the shelving on which is housed the craniological collection collapsed and about twenty skulls were damaged, but most of them not irreparably. Anatomical specimens, also in the wall cases, escaped major damage. Specimen jars were cracked or broken, but no specimens were lost. Room $\mathrm{V}$ and the War Museum have also been damaged. Roof lights in Room $\mathrm{V}$ were broken and most of the windows of the War Museum were smashed. About one hundred specimen jars were either broken or eracked, but all the specimens were retrieved and identified.

Precautions which had been taken to protect the Museum specimens worked admirably. Historic specimens and a complete series of pathological material suitable for medical students were stowed in a safe place almost two years ago, the idea being, that if the remainder of the Museum were destroyed, its connexion with John Hunter and his work would be preserved, and its usefulness to coming generations of students would remain unimpaired. Arrangements are now being made to remove at least the whole of the Periodical Collection in the Library to a safe place, so that, in the event of further air activity, at least one large series of medical periodicals would remain intact. The laboratories of the College suffered little damage beyond broken windows and wood frames, but as a precautionary measure the laboratories are being moved out of London.

\section{Museum of Practical Geology}

THE office block has been hit by a high explosive bomb. Two office rooms were damaged and about a quarter of the windows of the building were broken, together with others in surrounding buildings. Little damage was done to material in the Museum.

\section{Royal Observatory, Greenwich}

ThE Observatory has been damaged by high explosive and incendiary bombs. The revolving globe and observatory clock and parts of the telescope room were damaged, but the time ball continues to function.

\section{University of St. Andrews}

Most of the windows of one side of the University Library have been broken and damage has been done to books, especially those in the Science Reading Room. One wall of the new building housing the Departments of Botany and Geology has been seriously damaged, and the Bute Medical Buildings were also affected, much damage being done by the breakage of skylights and windows.

\section{University of Manchester}

THE University and the College of Technology have suffered certain damage. 